\title{
ウェアラブルセンサを用いた
}

熟練指導員のヤスリがけ技能主観評価値の再現

\section{Reproduction of Expert's Subjective Skill-Level Evaluation with Wearable Acceleration and Gyroscope Sensors on Metal-Filing}

\author{
榎堀 優 \\ Yu Enokibori \\ 間瀬 健二
}

名古屋大学 大学院情報科学研究科

Graduate School of Information Science, Nagoya University

enokibori@cmc.ss.is.nagoya-u.ac.jp, http://www.cmc.ss.is.nagoya-u.ac.jp/〜enokibori/

(同上)

mase@nagoya-u.jp, http://www.cmc.ss.is.nagoya-u.ac.jp/〜mase/

keywords: skill level evaluation, wearable, sensor, skill science, metal filing

\section{Summary}

On-demand, skill-level self-checks are required to establish effective training, and this is the same for metalfiling. However, such a training system has not been established yet for metal-filing because the current skill-level check depends on subjective skill-level estimation by experts. Such subjective skill-level estimation is composed of various complex viewpoints, and its estimation mechanisms cannot be represented in language because they are generated and supported by the experience of experts. That is why sensor-based, on-demand systems cannot faithfully imitate or replace the current skill-level checks of metal-filing. To solve this problem, we analyze the relationships among the subjective skill-level estimation mechanisms of experts and metal-filing mechanics structures. Our analysis yielded three simple viewpoints and related measures: class 2 lever-like movement measure $(L)$, upper body rigidity measure $(R)$, and pre-acceleration measure $(A)$. Surveys of experts also yielded another viewpoint and a related measure: stability measure $(S)$. These four measures successfully reproduced the subjective skill-level estimation of experts (adjusted- $\mathrm{R}^{2}=0.90, \mathrm{p}<0.1, \mathrm{~N}=10$ ). The coefficients for the measures, which suggest that $A$ is the main factor of the subjective skill-level estimation of experts, also suggest that effective training must emphasize these points in this order: $A>L>R$. S's coefficient suggests that the skill-level scores of experts are reduced by $69 \%$ when the filings of learners fail. In addition, since these four measures can be calculated with three small wearable hybrid sensors, they can be implemented on scalable wearable sensor-based skill-training systems. In future works, we will implement one such system, integrate it into a skill-training center's teaching plan, and assess how much the system improved the learning speeds of the students.

\section{1. は じめに}

本論文は , ウェアラブル加速度・角速度センサを用い たヤスリがけ技能分析結果と，光の結果を用いて熟練指 導員のヤスリがけ技能主観評価値を再現する手法につい て述べる . ヤスリがけ技能は，図 1 に示すように，ヤス リを用いて金属塊を削る動作である . 金属塊の切削面を 平らに削るという条件下で, 切削面にかかる力を最大化 する動作である . 弚の習熟過程は「作用点にかかる力が 最大化するように動作の力学構造を最適化していく」と いうバッティングやゴルフスイングなどと共通の特徵を 持つ.

熟練技能者のヤスリがけは, 未だに産業の根幹を支え ている．例えば，一品ものである新製品エンジンのプロ トタイプは, マザーマシーンから造出された段階でバリ や歪みを抱えていることがある. 炎の場合, 熟練技能者
が高精度のヤスリがけで修正することで, 造出し直しな どの無駄を無くしている .

一方で, 熟練技能者は急速に減少している. 主な原因 は, 熟練技能者の引退と若年層の製造業離れである.従つ て，技能者の効率的な育成が求められているが，ヤスリ がけ熟練者の育成は多大な時間を必要とする．例えば， WorldSkills International ${ }^{* 1}$ が主催する国際技能競技大会 (WorldSkills Competition: 通称 , 技能五輪) で幾人もの金 メダリストを輩出している技能研修所では, ヤスリがけ 技能の指導に数百時間を必要としている.

習熟に長時間を必要とする主な原因は, 現在のヤスリ がけ技能指導が「指導員の経験や勘といった暗黙的な経 験知に基づく主観評価とコーチング」に依存しているこ とである.訓練生は技能改善に向けた工夫をしても，谷の

\footnotetext{
${ }^{* 1}$ WorldSkills International: http://www.worldskills.org/
} 


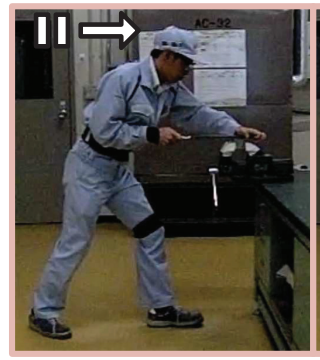

A

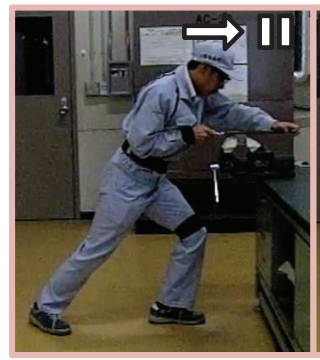

C

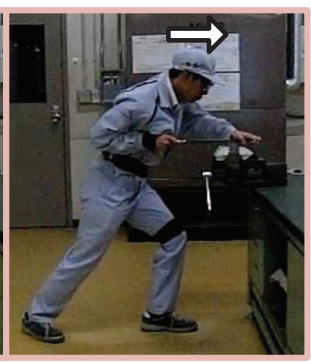

B

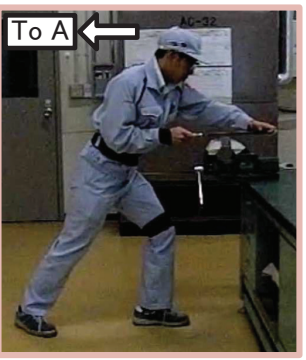

D
図 1 ヤスリがけ動作の主な 4 状態

A): 基本状態

B): 体の事前加速が終了,ヤスリが前方移動を開始, 切削開始

C): 体・ヤスリ共に前方移動が終了,切削終了

D): ヤスリを持ち上げつつ体が後方移動し，A に戻る

成否を指導員が観察して言語化するまで判断できず，次 の段階に進めない状況や習熟と逆方向へ努力し続ける状 況がたびたび発生している．加えて，指導員か訓練生の 工夫を見逃して成否評価をしないことや, 複数の指導員 が異なる主観評価やコーチングを行うことも珍しくなく， 技能習熟速度の鈍化の一因となっている。

一般的な技能習得と同樣に，ヤスリがけにおいても， 効率的な技能習得には訓練生自身が自己の状況を均質の 指標で随時確認できる環境が必要である．弚の実現には， 指導員らの経験や勘といった暗黙的な経験知に基づく主 観評価值を，センサなどを用いて再現するシステムの実 現が必要であるが，ヤスリがけにおいて，これは未だな されていない .ヤスリがけにおける指導員らの主観評価 は, 各々の経験に基づき多種多樣な評価軸があり，直接 的に再現することは現実的ではない，例えば，5名の熟 練指導員が同意して言語化できた評価軸だけでも 9 項目 となった (表 1)．また，項目 4 や項目 6 のように画像処 理やモーションキャプチャ, 敷設型の赤外線センサなど の大がかりな機材が無けれは観測しづらい評価軸もあり， 多数の訓練生が同時に利用する主観評価値再現システム の構築に不向きである .さらに, 表 1 のように言語化で きたとしても，どのような評価値を訓練生に割り当てる かは, 依然として指導員の経験や勘に基づいており，光 れらの暗黙的経験知とセンサなどで計測できる物理量と の関係を明らかにする必要がある .

そこで我々は, 熟練指導員らへのヒアリングから得ら れた形式知としての評価軸を直接利用せず，指導員らの
表 1 熟練指導員の主観評価項目

1) 体重のかけ方: 上半身の沈み込み

2) 体重のかけ方: 前足の踏み込み

3) 手首を胸に近づけて体で押しているか

4) ヤスリと腕が直線状にあるか

5) ヤスリの上に顔があるか

6) バイス台のハンドルと左足のつま先位置の合致

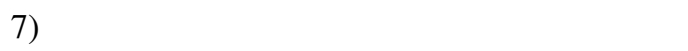

8) 体の軸の傾き (前傾姿勢)

9) ヤスリの先端から根本まで利用した切削

主観評価を「ヤスリがけ動作の基礎要素を複合的に判断 したもの」として捉え, 基礎要素から導出した評価尺度 を用いて指導員らの総合的な主観評価値を再現すること を目指し，これに成功した。

本研究では, ヤスリがけ動作の構造を「作用点にかか る力を最大化する力学構造」として捉え, 簡素な力学構 造の当て嵌めから 3 つの基礎要素を導出し, 各要素から 評価尺度を構築した . また, 兴の妥当性を元技能五輪選 手の熟練指導員らと訓練生らのセンサデータ比較により 確認した . 加えて, 熟練指導員へのヒアリングから安定 性尺度を追加導入し, 合計 4 つ評価尺度と表 1 に示し た熟練指導員による主観評価 (9 項目各 2 点 18 点満点 10 名分) との間に, 修正 $\mathrm{R}^{2}=0.90(\mathrm{p}<0.1)$ の高い相関性 を確認した。

なお，提案尺度の導出に簡素な力学構造を用いたのは， 再利用性が高い比較的廉価な小型のウェアラブル加速度・ 角速度センサのみで計測可能とするためである .これに より, 設置型の設備が不要となり, 多数の訓練生が同時 に利用できる主観評価値再現システムを実現できる．加 えて, 指導時の言語化が容易であるという利点も得た .

以下, 本論文は 2 章で関連研究について述べ, 3 章で ヤスリがけ動作と取得したセンサデータについて概説す る. 4 章は本研究で策定した評価尺度を説明する .5 章で 熟練指導員の主観評価と提案尺度の関連性分析と評価値 再現に付いて述べ, 6 章でまとめる .

\section{2. 関 連 研 究}

各種技能の身体動作分析や，熟練者と学習途上者の身 体動作比較は, 芸術, ヘルスケア，スポーツといった多 岐にわたる分野で研究されている.

Yamamoto ら [Yamamoto 08] はモーションキャプチャ を用いて陶芸における練りの動作について分析している． Matsumura ら [Matsumura 11]や Kawakami ら [Kawakam 08]はサンバにおけるリズム感と身体部位ごとの動作の関 係について分析している . Jafari ら [Jafari 07] はへルスケ アの分野における人体動作計測を加速度センサで行ってい る.スポーツ分野では, ウェアラブルセンサを用いた技能 分析が特に盛んである [Murata 01, Theobalt 04, Komura 
02, Lapinski 09, Ghasemzadeh 09, Heinz 06, Spelmezan 09] .

スポーツ分野では熟練者と学習途上者を区分する研究 も活発である. Ghasemzadeh ら [Ghasemzadeh 11] は 3 軸加速度センサ及び 2 軸ジャイロスコープを用いて，野 球のスイング動作について技能レベルを評価している Ahmadi ら [Ahmadi 09] は人体にジャイロスコープとマー カを取り付け , テニスのサーブの技能レベルを評価して いる . Ahmadi らは, 腕や肩の回転, ラケットのヘッドス ピードなどを総合的に評価し，4名の異なる技能レベルの プレイヤの切り分けに成功している. Bächlin ら [Bächlin 11] は, 手首, 背骨上部, 背骨下部に加速度センサを取 り付け, 熟練者 7 名・中級者 8 名・初級者 3 名の水泳の 技能レベルを評価している. Robinson ら [Robinson 11] は加速度センサによりカヤックの技能レベルを評価して いる. 炎の結果，オリンピックレベルのコーチが発見で きなかったパドリングの評価ポイントを導出している .

ウェアラブルセンサを用いて技能レベルを数值化し， 熟練者の主観評価を再現する研究としては, Harding ら [Harding 07, Harding 08a, Harding 08b] の研究が上げら れる. Harding らは慣性センサ及び 3 軸加速度センサを 腰に装着し , スノーボーダーの技能レベルを評価してい る.この評価結果は熟練審判による評価と強い相関を示 した .また，Harding らは16 名の国際級熟練審判にイン タビューを行い，新たな評価尺度の作成も試みている．

上記の樣に芸術やへルスケア, スポーツといった幅広 い分野において技能分析が行われており，スポーツ分野 ではウェアラブルセンサを用いた技能レベルの切り分け や数値化, 熟練者の主観評価の再現も試みられている.ヤ スリがけについては, Kojima ら [Kojima 09]が多視点の カメラ画像とウェアラブル加速度センサを用いて , ピー ク值の出現タイミングの観点から技能を分析している しかし, ヤスリがけの体全体の動きに対する分析が不足 しており, 加えて, 導出した分析結果と技能レベル間の 関係性分析, 技能レベルの数值化, 導出した数值と熟練 者の主観評価値との関係性分析は行われていない. 本研 究では, ヤスリがけにおける体全体の動きに対する分析 を行い, 弚の結果と技能レベル間の関係性を明らかにし て, 熟練者の主観評価值を再現することに成功した．

\section{3. ヤスリがけ動作とセンサデータ}

本節では，基礎知識の共有を目的にヤスリがけ動作の 概要を説明する. 加えて, 本研究で用いたセンサデータ の詳細について述べる .

\section{$3 \cdot 1$ ヤスリがけ動作の概要}

ヤスリがけ動作を主な4つの状態に分け，図 1 に示す． 技能者は, まず初期状態 A から体を前方へ事前加速して 切削で消費するエネルギーを貯める .この時，ヤスリは
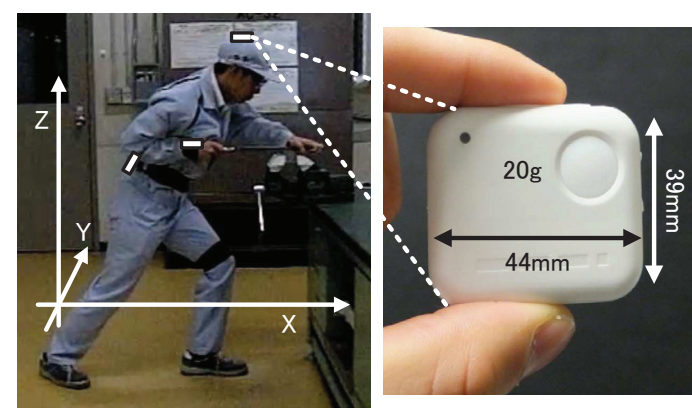

図 2 ハイブリッドセンサ WAA010 と装着箇所

表 2 WAA010 のセンサ性能とサンプリング設定

\begin{tabular}{lcr}
\hline \hline & 加速度センサ & ジャイロセンサ \\
\hline 軸数 / 電池寿命 & 3 軸 / 約 6 時間 \\
通信プロトコル & Bluetooth Ver. $2.0+$ EDR \\
通信可能距离隹 & \multicolumn{2}{c}{$10 \mathrm{~m}$} \\
最大サンプリングレート & $1000 \mathrm{~Hz}$ & $1000 \mathrm{~Hz}$ \\
最大検出範囲 & $\pm 2 \mathrm{G} \mathrm{to} \pm 16 \mathrm{G}$ & $\pm 2000 \mathrm{deg} / \mathrm{s}$ \\
\hline \hline \multicolumn{3}{c}{ 本研究で用いたサンプリング設定 } \\
\hline サンプリングレート & $100 \mathrm{~Hz}$ & $100 \mathrm{~Hz}$ \\
最大検出範囲 & $\pm 8 \mathrm{G}$ & $\pm 2000 \mathrm{deg} / \mathrm{s}$ \\
\hline
\end{tabular}

地磁気センサは本研究で利用していないため記載を省略した .

殁ど動いていない．体が十分に加速しつつ前傾し，ヤス リ後方を支える腕の肘 (図 1 の場合は右肘) が十分に締 まって固定されると，ヤスリへ力を効率よく伝えられる 図 1 のB の姿勢となる .この図 1 の B の時点からヤスリ の前方移動が始まり, ヤスリの先端から根本までを使っ て切削する. 弚の後, 図 1 のCの状態で切削が終了する. 切削が終了した後，図 1 のDのようにヤスリを持ち上げ て金属面との接触を断ちつつ，体とヤスリを後方移動し て, 図 1 のAの状態へ戻る.以降, これを繰り返す.

\section{$3 \cdot 2$ センサデータの収集と事後処理}

本研究ではWAA010*2 を頭, 腰, ヤスリ後方を支える 腕の手首 (以後, 頭, 腰 , 手首のセンサと呼称する) に装 着して加速度データ及び角速度データを取得した . 図 2 にセンサの外観と装着箇所を示す . 表 2 にセンサ性能と データ取得時のサンプリング設定を示す . 4 名の熟練指導 員と 10 名の訓練生からヤスリがけ開始 10 秒後から切削 30 回分のデータを収集した．被験者は全て男性である． 取得したデータに最大検出範囲を超えた箇所は存在しな かった. 取得したデータは 11 点単純移動平均で平滑化し， 角速度を積算した值を用いて加速度をセンサ座標系から 世界座標系に変換した . 変換後の軸を図 2 に示す . 加え て, 変換後の加速度を積算して各部位の速度データを導 出した .なお，ヤスリがけ動作の前後に 5 秒間の静止時

\footnotetext{
${ }^{* 2}$ ATR-Promotions 小型無線ハイブリッドセンサ II(WAA010): http://www.atr-p.com/sensor10.html
} 


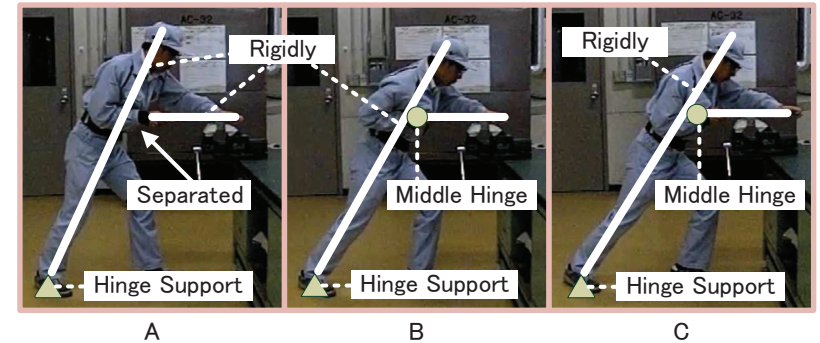

図 3 待機状態から切削終了までの力学構造 (A から C は図 1 の A から C に対応する)

間を設け, 前後の静止時間における積算加速度及び積算 角速度が 0 になるように誤差とドリフト值を排除した。

\section{4. ヤスリがけ動作の評価尺度}

本研究では,ヤスリがけ動作の構造を「作用点にかか る力を最大化する力学構造」として捉え, 図 3 に示す簡 素な力学構造の当て嵌めから 3 つの基礎要素を導出した . 加えて, 指導員らへのヒアリングから安定性尺度を導入 し, 計 4 つの評価尺度を用いた . 本節では, 各評価尺度 の詳細と弚の妥当性について述べる。

各尺度の説明に先立ち, 共通して用いる図表として図 3 と図 4 を概説する . 図 3 は, 図 1 の A から C の動作の 力学構造*3 である. 图 4 は熟練指導員と訓練生の典型的 な一回の切削をX軸方向速度についてグラフ化したもの である.グラフ化に利用した熟練指導員と訓練生は, 熟

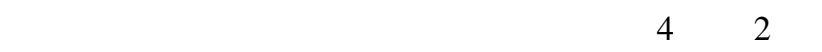
手と 10 名中 5 番手の被験者である. 各被験者の 30 回の 切削中から，目視で差が明確である切削を選択した .

以後, 本稿ではX 軸方向の速度のみを扱う. 速度と表 記する場合 , 明記がない限り各部位のX 軸方向の速度を 指すものとする .なお，各尺度の詳細な計算式は付録に 譲る。

\section{$4 \cdot 1$ 第 2 種梃子状動作尺度 $(L)$}

我々は，ヤスリがけ動作を図 3 に示すように，後方の 足を回転支点 (HingeSupport) とした第 2 種梃子状の構造 で近似した .この構造は, 上体に蓄えられたエネルギー を作用点であるヤスリの切削面で増幅し，効率的な切削 を可能とする .

実際のヤスリがけ動作が第 2 種梃子状構造で動作して いることは , 図 4 に示した $b$ 時点における熟練指導員の 頭と腰の速度比から裏付けられた . 物体が円運動をする 場合 , 各部の速度比は中心点からの距離の比と同じにな る. 熟練指導員の頭部速度が最高となったときの頭と腰

\footnotetext{
*3熟練指導員からのコメント「図 1 の B から $\mathrm{C}$ へ移行する切 削時は, 前方の脚 (図 3 では左足) に体重を掛かけないことがコツ 極端に言えば前方の足は浮いていても良い」を考慮し，前方の足は ヤスリガけ動作と無関係としている.
}



訓練生

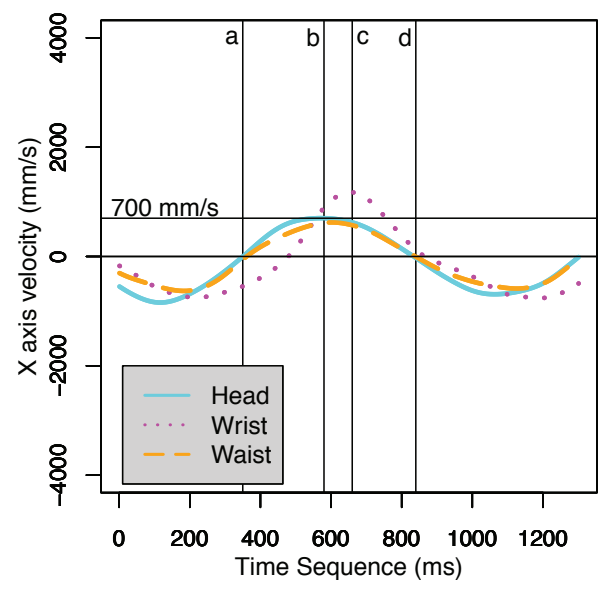

図 4 熟練指導員と訓練生の各部位の速度 縦線 a: 頭の速度の負から正へのゼロクロス . 图 3 の A . 縦線 b: 頭の速度の最高値 . 図 3 の B .

縦線 c: 手首の速度の最高值. 図 3 の B と C の間 .

縦線 d: 頭の速度の正から負へのゼロクロス . 図 3 のC .

の速度比は熟練指導員 4 名の平均で $1.64 \pm 0.22$ 対 1 で あり, 身長と腰高の比である $1.67 \pm 0.05$ 対 1 と近い值 を取った .これは熟練指導員のヤスリがけ動作は, 後ろ 足から頭頂部にかけての動作が後ろ足を回転支点とした 第 2 種梃子状動作であることを裏付けている。

一方で, 訓練生 10 名の $\mathrm{b}$ 時点での頭と腰の速度比は平 均で $1.23 \pm 0.26$ であり，経済産業省による人間特性基盤 整備事業 (size-JPN) 2004-2006*4 による 20 歳台から 40 歳台の日本人の平均身長と平均腰高 ${ }^{* 5}$ の比である約 1.7 対 1 より低く, 第 2 種梃子状動作が行えていないことが 分かる.

従って，第 2 種梃子状動作を行えているかどうかは， ヤスリがけ動作の習熟度合いの目安とできる、本研究で は，これを第 2 種梃子状動作尺度 ( $L$ (Class 2 Lever like

\footnotetext{
${ }^{* 4}$ size-JPN 2004-2006:

http://www.meti.go.jp/press/20071001007/20071001007.html

${ }^{* 5}$ size-JPN 2004-2006 には腰高のデータが無いため肘頭高-3cm で代用した . 肘頭高は「床面から直角に曲げた肘の骨の下端までの 鉛直距離」であり，センサ装着部である腰より幾ばくか高い，乥こ で $3 \mathrm{~cm}$ を腰と肘頭高の概算距離として差し引いた .
} 
Movement Measure)) とした .

\section{$4 \cdot 2$ 上体剛体化尺度 $(\boldsymbol{R})$}

技能者が効率よく金属面を削るためには，力が全てヤ スリ面へ作用すること，つまり，図 3 のBに示すように， 支点とヤスリ面との間にある人体及びヤスリが自由度を 失って一塊の剛体のように振る舞い, 力を他に逃がさな い状態が必要だと推測される．以下, 本稿では, 本来は 可変である人体を, 筋力で支えたり関節可動域の制限で 固定したりすることで, あたかも剛体のように作用させ ることを剛体化と呼ぶ .

熟練指導員の切削において, 上体の岡体化が行われて いることは, 図 4 に示した頭と手首の速度から裏付けら れる. 図 4 の熟練指導員のグラフでは, 手首の最高速度 点 (縦線 c) から切削終了点 (縦線 d) の間において, 頭と 手首の速度が近い值を取り，同期して動いている．これ は上体が一塊となって動いていることを示す．一方，訓練 生のグラフは, 頭の速度が先に減速している .これは体 の動きが先に止まり，腕の力だけで切削したためである．

数値としても, 手首の最高速度点 (縦線 c) から切削終 了点 (縦線 d) の間の頭と手首の速度差の絶対值は, 熟練 指導員 4 名の平均で $184.21 \pm 43.64(\mathrm{~mm} / \mathrm{s})$, 訓練生 10 名の平均で $222.62 \pm 84.00(\mathrm{~mm} / \mathrm{s})$ となり，熟練指導員 の方が速度差が小さい $\left(\mathrm{p}<0.01^{* 6}\right)$. また，頭と手首の 速度のスピアマン相関係数は, 熟練指導員 4 名の平均で $0.93 \pm 0.02$ (全て $\mathrm{p}<0.01)$, 訓練生 10 名の平均で 0.61 \pm 0.24 (全て $\mathrm{p}<0.01)$ となり, 熟練指導員の方が同期し た動きをしている $\left(\mathrm{p}<0.01^{* 6}\right)$.

以上のことから，切削時の上体剛体化度合いはヤスリ がけ動作の習熟度合いの目安とできる . 本研究では , こ れを上体剛体化尺度 ( $R$ (Upper Body Rigidity Measure)) とした.

\section{$4 \cdot 3$ 事前加速尺度 $(A)$}

$3 \cdot 1$ 節におけるヤスリがけ動作の分析から，技能者は 切削前に加速して切削に使うエネルギーを貯めているこ とが分かっている. 熟練指導員 4 名の頭部最高速度の平 均は $1319.45 \pm 274.11(\mathrm{~mm} / \mathrm{s})$, 訓練生の頭部最高速度 は $581.48 \pm 149.53(\mathrm{~mm} / \mathrm{s})$ であり, 熟練指導員の頭部最 高速度は訓練生の最高速度よりも大きい $\left(\mathrm{p}<0.01^{* 6}\right)$. 従って，切削時の頭部最高速度はヤスリがけ動作の習熟 度合いの目安とできる. 本研究は, これを事前加速尺度 (A (Pre-Acceleration Measure) ) とした .

\section{$4 \cdot 4$ 安定性尺度 $(S)$}

前述の 3 尺度によって，訓練生を評価したところ，明 らかに指導員の主観評価と乘離した評価が, 数人の訓練 生に見受けられた . 乥れに対して指導員にヒアリングを

\footnotetext{
${ }^{* 6}$ K-sample Anderson-Darling Tests[Scholz 87]
}

実施したところ，評価が承離していた訓練生は 30 回の 切削中に数回の引つかかりが発生していることが分かっ た．乥こで切削が安定的しているかどうかを表現する安 定性尺度 ( $S$ (Stability Measure) ) を導入した。

\section{5. 提案評価尺度による熟練指導員の主観評価 值の再現}

我々は, 前章で構築した 4 種類の評価尺度と訓練生 10 名に対する熟練指導員の主観評価値から，重回帰分析と 残差偏差の最小化によって熟練指導員の主観評価値を再 現した (修正 $\left.\mathrm{R}^{2}=0.90, \mathrm{p}<0.1, \mathrm{~N}=10\right)$.

本節では, まず収集した熟練指導員の主観評価値の詳 細について述べる . 次に，重回帰分析での利用に向けて 尺度 $L, R, A$ 間の相関度合いを確認した結果について述 ベる. 兴の後, 重回帰分析に用いた式, 並びに, 重回帰 分析結果の解釈について述べる.

\section{$5 \cdot 1$ 熟練指導員の主観評価值収集と事後処理}

熟練指導員 4 名 (全て元技能五輪選手) と訓練生 10 名 に対する主観評価値を，前述の 4 名を含む熟練指導員 5 名から収集した，収集ではヤスリがけの録画映像を利用 し, 評価は表 1 に示した 9 項目に各 2 点の 18 点満点と した . 光の後, 熟練指導員間の主観評価基準値のズレを 補正するため, 各熟練指導員の訓練生評価値の平均が 1 になるように正規化した . なお，前述のとおり，表 1 の 評価項目は熟練指導員らの相談によって決定されており， 各項目は指導員らの普段の指導・評価軸を反映したもの となっている．

取得した評価値の内，熟練指導員に対する主観評価値 は，重回帰分析に利用していない．これは，熟練指導員が 全て同じ組織に属しており，役職上の上下関係があるな ど，心理的バイアスが強く発揮され，比率尺度として不 適当であると考えられるためである．従って，熟練指導 員に対する主観評価値は重回帰分析による重み推定には 用いず, 順序尺度として推定結果の解釈にのみ利用した．

\section{$5 \cdot 2$ 尺度 $\boldsymbol{L}, \boldsymbol{R}, \boldsymbol{A}$ の相関}

重回帰分析に用いる説明変数同士は強い相関を持たな いことが望ましい．しかし，尺度 $L, R, A$ は導出に用い る加速度センサ值を共有しているため, 強い相関を持つ 可能性がある . 本研究では, 被験者ごとの 30 回の切削 に対して , スピアマン相関係数の算出と検定を行い，尺 度 $L, R, A$ の相関を確認した . 図 5 に熟練指導員と訓練 生に分けた箱ひげ図として結果を示す。

相関係数は-0.38 から 0.85 まで広く分布しており，定 まった傾向は見られない．また， $\mathrm{p}$ 值の分布から，全て の尺度間において , 相関があるとも相関がないとも言い 切れない．やや高い相関係数を示したのは，訓練生の尺 度 $L, A$ 間の相関係数であり $0.59 \pm 0.24$ である . p 值 

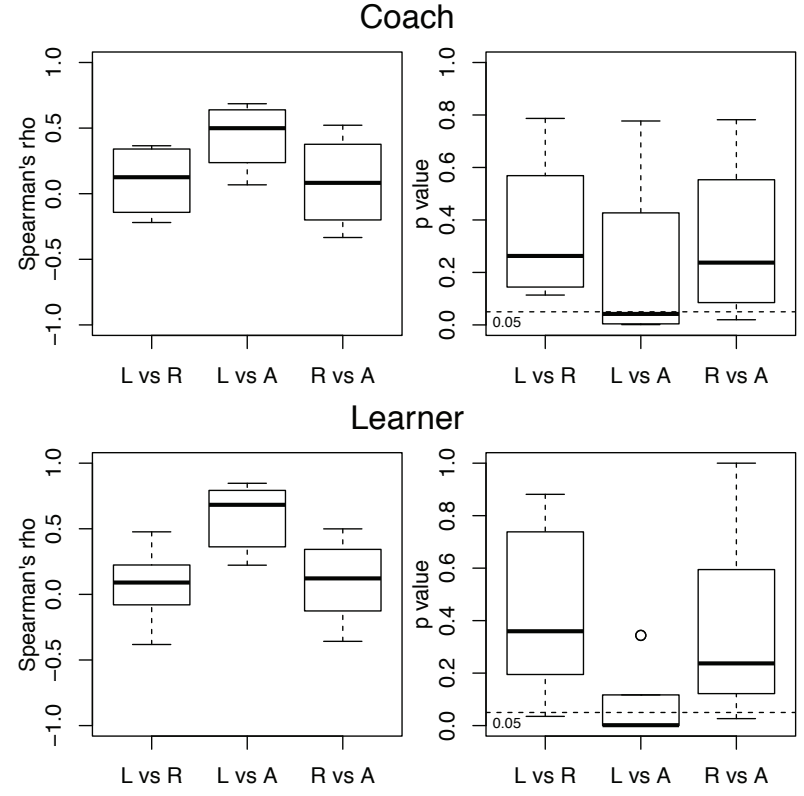

図 5 提案尺度 $L, R, A$ 間のスピアマン相関係数 (上段: 熟練指導員，下段: 訓練生)

$<0.05$ となった割合も 0.7 であった . しかし, 熟練指導 員の尺度 $L, A$ 間の相関係数は, $0.43 \pm 0.27$ と訓練生よ り低い值を示し, $\mathrm{p}$ 值 $<0.05$ となった割合も 0.5 と訓練 生より低い值を取った . 従って, 訓練生の尺度 $L, A$ 間の 相関係数はやや高い值を示しているが, 上達するに従っ て相関か溺くなる傾向にあると考えられる．

以上から提案尺度 $L, R, A$ 間に強い相関はなく, 重回帰 分析に用いる尺度として妥当な尺度であると考えられる．

\section{$5 \cdot 3$ 重回帰分析と残差最小化による重み推定}

本研究で重回帰分析に用いた式を式 (1)に示す.なお， 付録に譲った尺度の計算式が示すとおり， $L, R, A$ は熟 練指導員でおよ光 1 を示す。

$$
\begin{aligned}
\text { score }= & \left(w_{1} L+w_{2} R+w_{3} A\right. \\
& +w_{4} L R+w_{5} R A+w_{6} A L \\
& \left.+w_{7} L R A\right)\left(1-w_{s} S\right)+b \\
S= & \begin{cases}1, & \text { 切削失敗時 } \\
0, & \text { 切削成功時 }\end{cases}
\end{aligned}
$$

本研究では, 4 章で導出した 4 尺度と訓練生 10 名に 対する熟練指導員の主観評価値 (score) を用いて, 式 (1) で重回帰分析を行い，重み $w=\left(w_{1}, w_{2}, w_{3}, w_{4}, w_{5}, w_{6}\right.$, $\left.w_{7}\right)$ ，及び，切片 $b$ を推定した．重み $w_{s}$ は重回帰分析 では求めず，重回帰分析後の残差が最小になる值を 0 か ら 1 の範囲で選択した . $w_{s}$ は安定性尺度 $(S)$ に関連して おり，切削失敗時に評価を $w_{s}$ の割合で低減する効果が ある

なお， $5 \cdot 2$ 節で示したとおり， $L, R, A$ の間は強い相 関があるとは言い切れないが，無相関とも言い切れない .

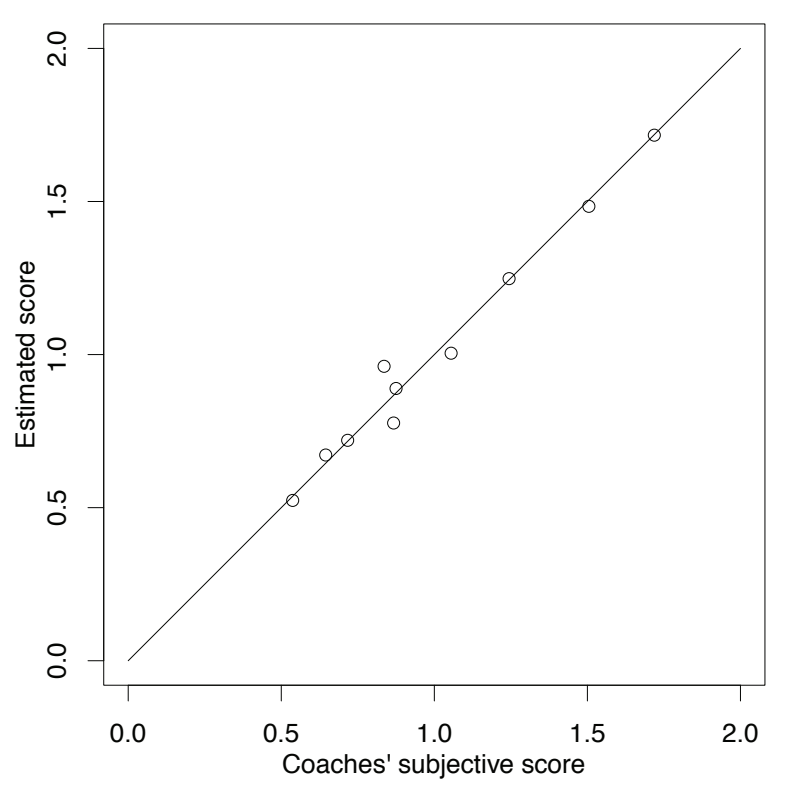

図 6 熟練指導員の主観評価と推定評価値の相関性

表 3 重回帰分析と残差偏差最小化による重み推定結果

\begin{tabular}{lr|lr}
\hline \hline 修正 $\mathrm{R}^{2}$ & 0.90 & $w_{3}$ & 133.77 \\
$\mathrm{p}$ 値 & 0.07 & $w_{4}$ & -119.45 \\
残差偏差 & 0.12 & $w_{5}$ & -162.15 \\
$b$ & -60.68 & $w_{6}$ & -209.23 \\
$w_{1}$ & 99.20 & $w_{7}$ & 255.57 \\
$w_{2}$ & 73.55 & $w_{s}$ & 0.69 \\
\multicolumn{4}{l}{ 値は全て小数点以下第 3 位で四捨五入した . }
\end{tabular}

そこで 2 尺度交差項と 3 尺度交差項を導入した．また， 赤池情報量規準 (AIC) 值を用いた変数減少ステップワイ ズ法により，式 (1) が最小の AIC 值として-42.74 を示す ことを確認した .

推定結果を表 3 に, 熟練指導員の主観評価と重回帰分 析結果を用いた推定評価値の相関性を図 6 に示す。

\section{4 重回帰分析結果の解䣋}

修正 $\mathrm{R}^{2}$ は $0.90(\mathrm{p}<0.1)$ であり，高い相関が示され た .これは, 定義した 4 つの評価尺度により, 熟練指導 員の主観評価を十分に再現できることを示している，提 案尺度はヤスリがけ動作の力学構造から導出したもので あり，本結果は，熟練指導員らが表 1 に示した主観評価 軸の点数付けに用いる経験や勘といった暗黙的経験知と ヤスリがけの力学構造との間の関係を明らかにしたもの と言える

$w_{3}>w_{1}>w_{2}$ より，熟練指導員の主観評価 (表 1) は， 事前加速尺度に代表されることが分かる . また, 事前加 速尺度, 第 2 種梃子状動作尺度, 上体剛体化尺度の順に 優先度を付けて指導することで, 効率的な技能習得が期 待できるものと予想される .

$w_{s}$ は 0.69 を示しており，これは失敗した切削につい 


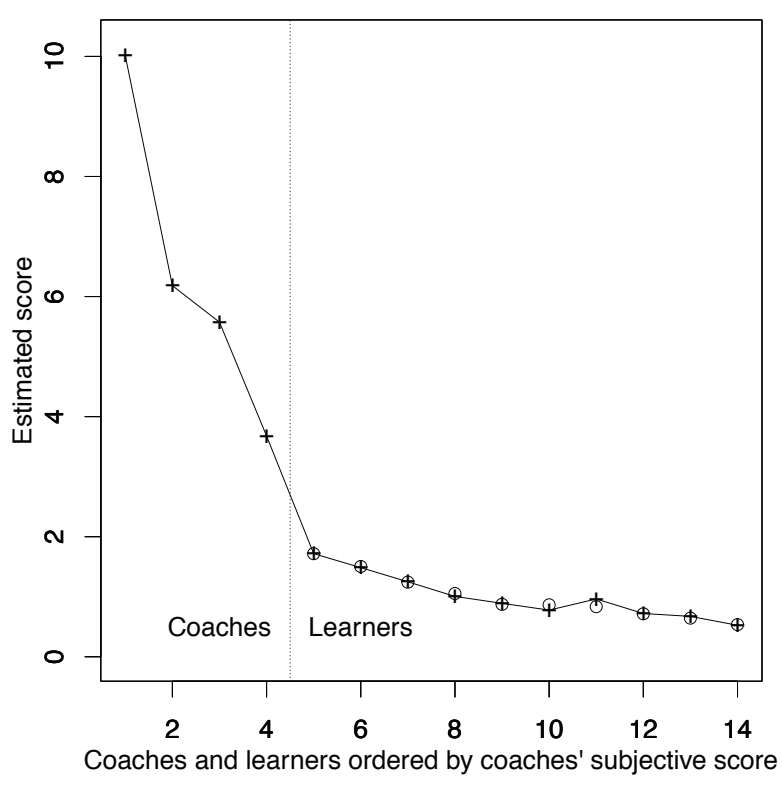

図 7 熟練指導員と訓練生を合わせた推定評価値 注: ○は熟練指導員による訓練生への主観評価値

て熟練指導員らか評価値を約 7 割削減していたことを示 している.ヒアリングにおいて熟練指導員らは「引つか かることは希に発生するので, 弚の部分は考慮せず評価 することが多い」と述べていたが，実際には無意識に減 点していたことになる.従って, 熟練指導員らか認識して いなかった暗黙知の一つを導出できたものと考えられる なお，2 尺度交差項の重みがマイナスだが , これは各項 に共通して内在する要素か油出されて, 重複分を相殺して いると解釈できる.例えば $L=A B, R=B C$ と共通要素 を内包する場合， $L R=A B^{2} C$ である . $w_{1} L+w_{2} R-$ $w_{3} L R=w_{1} A B+w_{2} B C-w_{3} A B^{2} C$ となり，第 3 項は 前 2 項で過度に強調された共通要素B を相殺している。 3 尺度交差項は $L, R, A$ の全要素に共通する要素を示して おり，切片に近い性質を持ち值の大小にかかわらず影響 は少なく，255.57 と大きな値を取ることに問題はない．

\section{$5 \cdot 5$ 熟練指導員への推定評価値による妥当性の検証}

5.3 節で決定した重みを用いて熟練指導員への推定評 価値を計算し, 訓練生への評価值と比較して妥当性を検 証した . 熟練指導員と訓練生の推定評価値のグラフを図 7 に示す．

图 7 のとおり，熟練指導員に対する推定評価値は全て の訓練生より高く，熟練指導員らの主観と合致した . ま た, 熟練指導員に対する推定評価値の順序も, 熟練指導 員に対する主観評価值の順序と合致しており，推定結果 が妥当である可能性が高い .

なお, 本研究では, 熟練指導員に対する主観評価値を 用いた検定や詳細な分析は行っていない．これは，サン プルが小数であることに加え, 同僚に対する主観評価値 には強いバイアスが含まれ，分析に不適当と考えられる ためである . 本件は今後の課題とする .

\section{6. ま と め}

本研究では, 数百時間に及、ぶヤスリがけ訓練時間の削 減に向けた効率的な技能習得方法の確立を目指した . 効 率的な技能習得には, 訓練生が自己の評価を均質の指標 で随時確認できることが重要であり，熟練指導員らの経 験と勘に基づく主観評価を，センサなどを用いて再現す る必要があった。弚こで本研究では, 指導員らの主観評価 を「ヤスリがけ動作の基礎要素を複合的に判断したもの」 として捉え, 基礎要素の評価値と訓練生に対する熟練指 導員の主観評価値による重回帰分析と残差偏差最小化か ら，高い相関性を得て (修正 $\left.\mathrm{R}^{2}=0.90, \mathrm{p}<0.1, \mathrm{~N}=10\right)$ ， 熟練指導員の主観評価値の再現に成功した .

導出した基礎要素は, ヤスリがけ動作の構造を「作用 点にかかる力を最大化する力学構造」とした簡素な物理

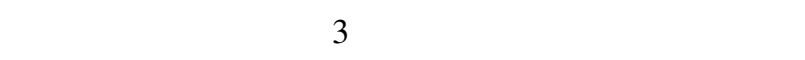
から 1 つの計 4 つであり，光れ光れから尺度を構築した (第 2 種梃子状動作尺度 $(L)$, 上体剛体化尺度 $(R)$, 事前 加速尺度 $(A)$, 安定性尺度 $(S))$. 重回帰分析の推定結果 から，熟練指導員の主観評価 (表 1) は, 事前加速尺度に 代表されることが分かった . 事前加速尺度, 第 2 種梃子 状動作尺度，上体剛体化尺度の順に優先度を付けて指導 することで，効率的な技能習得か期待できることも判明 した．また，失敗した切削の評価値を，熟練指導員が無 意識に約 7 割削減していたことも分かった。

提案尺度 $L, R, A$ はヤスリがけ動作の力学構造から導 出したものであり, 本結果は, 熟練指導員らが表 1 に示 した主観評価軸の点数付けに用いる経験や勘といった暗 黙的経験知とヤスリがけの力学構造との間の関係を明ら かにしたものと言える. 尺度 $S$ の係数も熟練指導員が無 意識下で行っていた減点を明らかにし, 熟練指導員らが 認識していなかった暗黙知の一つを導出できたものと考 えられる。

なお，本研究で用いたセンサは Bluetooth 経由でスマー トフォンなどの小型携帯端末と連携できるため, 小型携 帯端末ベースの自学自習/指導システムとして運用可能で ある．今後は提案システムを実際のカリキュラムを通じ て利用し，習得時間短縮効果を検証する。また，ヤスリ から金属塊にかかる圧力変化や切削時の足圧変化などの 分析を加え, 人体と周辺機器との相互作用の面からも分 析を進める .

\section{謝辞}

本研究の一部は科学技術交流財団の共同研究推進事業 の支援を得ました . データ計測と分析にこ協力いただい た株式会社デンソー技研センターの皆さまに深く感謝い たします． 
$\diamond$ 付 録 $\diamond$

\section{A. 評価尺度の計算式}

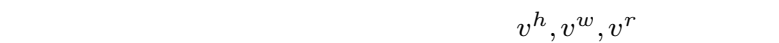
值の最高値を $v_{\text {max }}^{h}$ のように表す . $v^{h}$ が負から正になるポイント (图 4 の縦線 a) を時刻 0 とし時刻 $t$ における速度を $v^{h}(t)$, 最高値 時の時刻を $t\left(v_{\text {max }}^{h}\right)$ と表す. $v^{h}$ が正から負になるポイント (図 4 の縦線 d) の時刻を $t\left(v_{\text {last }}^{h}\right)$ と定義する . また ，熟練指導員 (Coach) や訓練生 (Learner) を明記する必要が有る場合, $v^{c}, v^{h, c}, v^{l}, v^{h, l}$ な どと右上添字に $\mathrm{c}$ や 1 を付加する .

$\mathbf{A} \cdot \mathbf{1}$ 第 2 種梃子状動作尺度 $(\boldsymbol{L})$

$4 \cdot 1$ 節のとおり，後ろ足を支点とした第 2 種梃子状動作ができて いれば, 頭と腰の最高速度の比は身長と腰高の比と近しくなる . ま た，4.1 節で示したとおり，経済産業省による人間特性基盤整備事 業 (size-JPN) 2004-2006 によれば, 20 歳台から 40 歳台の日本人の 平均身長と平均腰高の比は約 1.7 対 1 である. 従って, $L$ の計算式 を式(A.1) とした . 定義から $L$ は平均的な日本人男性が適切に第 2 種手梃子状動作を行えていれば 1 を示す。

$L=1-\left|1-\frac{v_{\max }^{h} / v_{\max }^{w}}{1.7}\right|$

\section{A.2 上体剛体化尺度 $(\boldsymbol{R})$}

$4 \cdot 2$ 節で述べたとおり，上体の剛体化ができていれば，切削時の $v^{h}$ と $v^{r}$ の差は小さくなる .一方, 最高速度が高速であるほど正 確な制御が困難となり， $v^{h}$ と $v^{r}$ の差は大きくなると考えられる . 従って, $v^{h}$ 又は $v^{r}$ の最高速度が高ければ, 多少の速度差を許容 することとし, 本研究では $R$ を式 (A.2) と定義した .

$$
\begin{aligned}
t_{s} & = \begin{cases}t\left(v_{\text {max }}^{r}\right), & t\left(v_{\text {max }}^{h}\right) \leq t\left(v_{\text {max }}^{r}\right)<t\left(v_{\text {last }}^{h}\right) \\
t\left(v_{\text {max }}^{h}\right), & \text { otherwise }\end{cases} \\
v_{\text {max }} & = \begin{cases}v_{\text {max }}^{r}, & t\left(v_{\text {max }}^{h}\right)<t\left(v_{\text {max }}^{r}\right) \\
v_{\text {max }}^{h}, & \text { otherwise }\end{cases} \\
r & =1-\frac{\sum_{i=t_{s}}^{t\left(v_{\text {last }}^{h}\right)} \frac{\left|v^{h}(i)-v^{r}(i)\right|}{v_{\text {max }}}}{t\left(v_{\text {last }}^{h}\right)-t_{s}} \\
R & =\frac{r}{r_{\text {mean }}^{c}}
\end{aligned}
$$

まず，最高速度が高いほど小さくなる重みを付けつつ，切削中に おける各時刻の $v^{h}$ と $v^{r}$ の差の平均値を求めて中間値 $r$ とする. その後, $r$ を熟練指導員の平均 $r$ 值 $\left(r_{\text {mean }}^{c}\right)$ で除算し, $R$ か熟練 指導員で約 1 を示すように調整した. 本研究では熟練指導員 4 名 の各 30 回の切削から $r_{\text {mean }}^{c}$ を 0.88 とした .

\section{A.3 事前加速尺度 $(A)$}

$4 \cdot 3$ 節で述べたとおり，熟練指導員は $v^{h}$ の值が訓練生と比べて 大きい. 従って, 本研究では $A$ を熟練指導員 4 名の各 30 回の切削 における $v^{h}$ の最高値の平均值 $\left(\operatorname{mean}\left(v_{m a x}^{h, c}\right)\right)$ を用いて，A か熟 練指導員で約 1 を示すように式 (A.3) と定義した . 本研究における $\operatorname{mean}\left(v_{\text {max }}^{h, c}\right)$ は 1319.45 だった .

$$
A=\frac{v_{\max }^{h}}{\operatorname{mean}\left(v_{\max }^{h, c}\right)}
$$

\section{A.4 安定性尺度 $(S)$}

Dynamic Time Warping (DTW) により，通常時と異なる加速度波 形を検出した場合を失敗切削とした .ヤスリの引っかかりなどを検 知できる手首の加速度を計算に用いた . まず各切削を基準として他 の切削を DTW で評価し, 類似度 (以下, DTW 距離) を得る. 続い て, 他の切削に対する DTW 距離の中央値が最も小さい切削を基準 切削として採用する . 中央値を中心として, 基準切削までの DTW 距離 (以下, var) の間に通常の切削は分散していると仮定し, 中央 值から $2 v a r$ 以内にあるものを成功切削とした .

\section{$\diamond$ 参 考 文 献 $\diamond$}

[Ahmadi 09] Ahmadi, A., Rowlands, D., and James, D.: Towards a wearable device for skill assessment and skill acquisition of a tennis player during the first serve, Sports Technology, Vol. 2, No. 3-4, pp. 129-136 (2009)

[Bächlin 11] Bächlin, M. and Tröster, G.: Swimming performance and technique evaluation with wearable acceleration sensors, Pervasive and Mobile Computing (2011)

[Ghasemzadeh 09] Ghasemzadeh, H., Loseu, V., and Jafari, R.: Wearable coach for sport training: A quantitative model to evaluate wristrotation in golf, Journal of Ambient Intelligence and Smart Environments, Vol. 1, No. 2, pp. 173-184 (2009)

[Ghasemzadeh 11] Ghasemzadeh, H. and Jafari, R.: Coordination analysis of human movements with body sensor networks: A signal processing model to evaluate baseball swings, IEEE Sensors Journal, Vol. 11, No. 3, pp. 603-610 (2011)

[Harding 07] Harding, J. W., Small, J. W., and James, D. A.: Feature extraction of performance variables in elite half-pipe snowboarding using body mounted inertial sensors, in Proc. SPIE 6799, BioMEMS and Nanotechnology III, pp. 679917-679928 (2007)

[Harding 08a] Harding, J., Mackintosh, C., Martin, D., Hahn, A., and James, D.: Automated scoring for elite half-pipe snowboard competition: important sporting development or techno distraction?, Sports Technology, Vol. 1, No. 6, pp. 277-290 (2008)

[Harding 08b] Harding, J., Toohey, K., Martin, D., Hahn, A., and James, D.: Technology and Half-Pipe Snowboard Competition Insight From Elite-Level Judges (P240), The Engineering of Sport 7, pp. 467-476 (2008)

[Heinz 06] Heinz, E., Kunze, K., Gruber, M., Bannach, D., and Lukowicz, P.: Using wearable sensors for real-time recognition tasks in games of martial arts-an initial experiment, in IEEE Symposium on Computational Intelligence and Games, pp. 98-102 (2006)

[Jafari 07] Jafari, R., Bajcsy, R., Glaser, S., Gnade, B., Sgroi, M., and Sastry, S.: Platform Design for Health-Care Monitoring Applications, in Proceedings of the 2007 Joint Workshop on High Confidence Medical Devices, Software, and Systems and Medical Device Plugand-Play Interoperability, pp. 88-94 (2007)

[Kawakami 08] Kawakami, M. and Fujinami, T.: On the Effect of Performance Evaluation in Acquiring Samba Rhythm, in 10th Internatinal Conference on Music Perception and Cognition, 2008, pp. 132-139 (2008)

[Kojima 09] Kojima, K., Mase, K., Tokai, S., Kawamoto, T., and Fujii, T.: On-Body Multi-Sensor Analysis of Metal Filing Performance for Manufacturing Skill Training, IEEE International Symposium on Wearable Computing 2009 (ISWC'09), Advances in Wearable Computing 2009, pp. 21-28 (2009)

[Komura 02] Komura, T., Kuroda, A., and Shinagawa, Y.: NiceMeetVR: facing professional baseball pitchers in the virtual batting cage, in Proceedings of the 2002 ACM symposium on Applied computing, pp. 1060-1065 (2002)

[Lapinski 09] Lapinski, M., Berkson, E., Gill, T., Reinold, M., and Paradiso, J. A.: A distributed wearable, wireless sensor system for evaluating professional baseball pitchers and batters, in IEEE International Symposium on Wearable Computers 2009 (ISWC'09), pp. 131-138 (2009)

[Matsumura 11] Matsumura, K., Yamamoto, T., and Fujinami, T.: The role of body movement in learning to play the shaker to a samba rhythm: An exploratory study, Research Studies in Music Education, Vol. 33, No. 1, pp. 31-45 (2011)

[Murata 01] Murata, A.: Shoulder joint movement of the nonthrowing arm during baseball pitch-comparison between skilled and unskilled pitchers, Journal of Biomechanics, Vol. 34, No. 12, pp. 1643-1647 (2001)

[Robinson 11] Robinson, M., Holt, L., Pelham, T., and Furneaux, K.: Accelerometry Measurements of Sprint Kayaks: The Coaches' New Tool, International Journal of Coaching Science, Vol. 5, No. 1, pp. 45-56 (2011)

[Scholz 87] Scholz, F. and Stephens, M.: K-sample AndersonDarling tests, Journal of the American Statistical Association, Vol. 82, No. 399, pp. 918-924 (1987)

[Spelmezan 09] Spelmezan, D., Schanowski, A., and Borchers, J.: 
Wearable automatic feedback devices for physical activities, in Proceedings of the Fourth International Conference on Body Area Networks, BodyNets '09, pp. 1:1-1:8, ICST, Brussels, Belgium, Belgium (2009), ICST (Institute for Computer Sciences, SocialInformatics and Telecommunications Engineering)

[Theobalt 04] Theobalt, C., Albrecht, I., Haber, J., Magnor, M., and Seidel, H.-P.: Pitching a baseball: tracking high-speed motion with multi-exposure images, in ACM Transactions on Graphics (TOG), Vol. 23, pp. 540-547 (2004)

[Yamamoto 08] Yamamoto, T. and Fujinami, T.: Hierarchical organization of the coordinative structure of the skill of clay kneading, Human Movement Science, Vol. 27, No. 5, pp. 812-822 (2008)

\section{〔担当委員 : 西村 拓一〕}

2012 年 11 月 30 日 受理

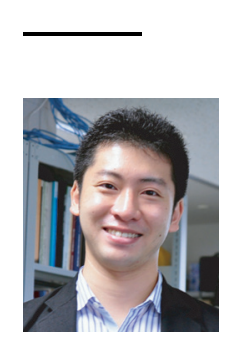

\section{紹 介}

\section{榎堀 優(正会員)}

2010 年 立命館大学大学院理工学研究科博士課程後期課程 修了. 2010 年 4 月〜2011 年 3 月同大助手. 2011 年 4 月 2013 年 3 月 名古屋大学情報科学研究科研究員. 2013 年 4 月 現在同特任助教. 2011 年 4 月 現在愛知県重 点研究プロジェクト 3 超早期診断技術開発プロジェクト G3S3 の研究に従事 . 専門分野: ユビキタス・ウェアラブル 情報処理学会, バイオメカニズム学会, 各会員. 博士 (工学) .

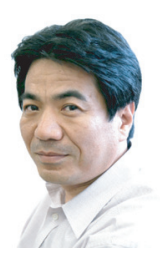

間瀬 健二(正会員)

1979 年名大.工学部・電気卒. 1981 年同大大学院工学研究 科修士 (情報) 課程修了. 同年日本電信電話公社 (現在 NTT) 入社. 1988-1989 年米国 MIT メディア研究所客員研究員 1995-2001 年 (株) ATR 知能映像通信研究所第二研究室室 長. 2001-2002 年 ATR メディア情報科学研究所第一研究 室室長. 2002 年より名古屋大学教授、現在同大学院情報 科学研究科所属. 人工知能学会 1999 年度論文賞. 電子情 報通信学会フェロー。博士 (工学) . 